\title{
Comparative cytogenetics of spiny rats of the genus Proechimys (Rodentia, Echimyidae) from the Amazon region
}

\author{
E.S. Eler ${ }^{1}$, M.N.F. da Silva ${ }^{2}$, C.E.F. Silva ${ }^{1}$ and E. Feldberg ${ }^{1}$ \\ ${ }^{1}$ Laboratório de Genética Animal, Instituto Nacional de Pesquisa da Amazônia, \\ Manaus, AM, Brasil \\ ${ }^{2}$ Coleção de Mamíferos, Instituto Nacional de Pesquisas da Amazônia, \\ Manaus, AM, Brasil \\ Corresponding author: E.S. Eler \\ E-mail: edueler@yahoo.com.br
}

Genet. Mol. Res. 11 (2): 830-846 (2012)

Received August 2, 2011

Accepted November 30, 2011

Published April 3, 2012

DOI http://dx.doi.org/10.4238/2012.April.3.5

\begin{abstract}
We made a comparative analysis of the cytogenetics of spiny rat species of the genus Proechimys collected from several sites of the Madeira River basin (Amazonas State, Brazil) and Jari River valley (Pará State, Brazil). Individuals were assigned to three groups based on diploid and fundamental numbers: $2 \mathrm{n}=28, \mathrm{FN}=46(P$. cuvieri and $P$. gr. longicaudatus); $2 \mathrm{n}=38, \mathrm{FN}=52$ (Proechimys gr. guyannensis), and $2 \mathrm{n}=40, \mathrm{FN}=54$ ( $P$. gardneri). The nucleolar organizer region (NOR) was interstitial on the long arm of one submetacentric pair, as seen in all species of Proechimys analyzed thus far. However, its position in the karyotype was variable. A duplication of the NOR in one of the homologues was detected in P. gr. longicaudatus from the Aripuanã basin along the mid Madeira. The C-band pattern varied between species and, together with the NOR, allowed the identification of two evolutionary units in $P$. gr. longicaudatus in the region of the mid Madeira River (cytotypes A and B). The morphology and banding of the sex chromosomes were species specific. A range extension is
\end{abstract}


suggested for the geographic distribution of $P$. gardneri and $P$. gr. longicaudatus. Moreover, we suggest that species of Proechimys with $2 \mathrm{n}=38$ chromosomes are restricted to east of the Negro River and north of the Amazon River. We also revised the published chromosome data available for Proechimys.

Key words: Chromosome banding; Cytotaxonomy; Cytotypes; Spiny rat

\section{INTRODUCTION}

Spiny rats from the genus Proechimys are among the most abundant Amazonian rodents and have extremely complex systematics. Moreover, there are a number of reports of species occurring in sympatry (Moojen, 1948; Patton and Gardner, 1972; da Silva, 1998; Patton et al., 2000). Patton (1987) landmark study on Proechimys systematics used qualitative morphological characters of the cranium, dentition and baculum to group 59 of the 67 available names at the time into nine distinct groups: $P$. guyannensis, $P$. goeldii, $P$. longicaudatus, P. simonsi, P. cuvieri, P. trinitatus, P. semispinosus, P. canicollis, and P. decumanus. Although it was not possible to recognize each species by morphological characters alone, due to geographic, age and sex variations within and among groups, these characters have been useful for differentiating sympatric species.

A number of authors stress the importance of the combination of morphological characters, chromosome traits and DNA sequencing associated with a finer geographic sampling for a better understanding of the existing diversity in Proechimys (Patton and Gardner, 1972; da Silva, 1998; Patton et al., 2000; Weksler et al., 2001; Machado et al., 2005). However, there is no robust phylogeny for this genus yet, which hinders the understanding of the kinship relations between species and the study of the evolution of characters, including chromosome evolution. Twenty-five species are currently assigned to this genus (Wilson and Reeder, 2005) and the number of known karyotypes is much higher (Weksler et al., 2001).

The aim of the present study was to analyze the chromosomes in species of Proechimys collected from two regions in the Brazilian Amazon to establish cytological markers or chromosomal modifications that might be implicated in either speciation or phyletic evolution among these rodents. When associated with other kinds of data, the cytogenetic information will also assist in the determination of the taxonomic limits of Proechimys species, their geographic distribution and the clarification of evolutionary processes.

\section{MATERIAL AND METHODS}

For cytogenetic analysis, 24 individuals of Proechimys were collected from two areas in the Amazon: in the region of the mid-Madeira River in the State of Amazonas, Brazil (9 males and 8 females), and a mosaic region of primary forest and areas with human development in the Jari River Valley in the State of Pará, Brazil (4 males and 3 females) (Table 1).

Mitotic chromosomes were obtained from bone marrow using the Ford and Harmerton (1956) "air-drying" method with modifications. Colchicine $(0.0125 \%)$ was used at a proportion of $1 \mathrm{~mL} / 100 \mathrm{~g}$ body weight. Cell material was hypotonized by a $0.075 \mathrm{M}$ potassium chloride solution, fixed in Carnoy fixer and stained with Giemsa. 
Table 1. Collection area, geographic location and registry number of the species analyzed (Proechimys).

\begin{tabular}{lll}
\hline Localities & $\begin{array}{c}\text { Geographic } \\
\text { location }\end{array}$ & Species/Specimen collection number \\
\hline Mid-Madeira River & & \\
Boca do Juma, & $06^{\circ} 00^{\prime} \mathrm{S}$ & $P$. gr. longicaudatus/INPA 4749, INPA 4762, INPA 4764, INPA 4789 \\
right bank of Madeira River & $60^{\circ} 10^{\prime} \mathrm{W}$ & \\
Açaí Lake, & $06^{\circ} 00^{\prime} \mathrm{S}$ & P. gr. longicaudatus/INPA 4754, INPA 4757 \\
left bank of Aripuanã River & $60^{\circ} 12^{\prime} \mathrm{W}$ & \\
Cachoeirinha, & $05^{\circ} 29^{\prime} \mathrm{S}$ & P. gardneri/INPA 4796 \\
left bank of Madeira River & $60^{\circ} 49^{\prime} \mathrm{W}$ & \\
Pau Rosa trail, & $06^{\circ} 17^{\prime} \mathrm{S}$ & P. gr. longicaudatus/INPA 5410 \\
right bank of Aripuanã River & $60^{\circ} 23^{\prime} \mathrm{W}$ & \\
Igarapé Arauazinho, & $06^{\circ} 17^{\prime} \mathrm{S}$ & P. gr. longicaudatus/INPA 5401, INPA 5414, INPA 4798 \\
left bank of Aripuanã River & $60^{\circ} 23^{\prime} \mathrm{W}$ & \\
Community Bela Vista (Xada Lake), & $05^{\circ} 14^{\prime} \mathrm{S}$ & P. gardneri/INPA 5376, INPA 5383, INPA 5390, INPA 5391, INPA 5395, INPA 5396 \\
left bank of Madeira River & $60^{\circ} 42^{\prime} \mathrm{W}$ & \\
Jari River Valley & $0^{\circ} 42^{\prime} \mathrm{S}$ & P. gr. guyannensis/INPA 5044, INPA 5045 \\
Trail 56* & $52^{\circ} 40^{\prime} \mathrm{W}$ & \\
Monte Dourado & $0^{\circ} 49^{\prime} \mathrm{S}$ & P. gr. guyannensis/INPA 5052, INPA 5053, INPA 5054 \\
Area 14* & $52^{\circ} 39^{\prime} \mathrm{W}$ & \\
Monte Dourado & $0^{\circ} 35^{\prime} \mathrm{S}$ & P. gr. guyannensis/INPA 5229 \\
Area 55* & $52^{\circ} 39^{\prime} \mathrm{W}$ & \\
Monte Dourado & $01^{\circ} 11^{\prime} \mathrm{S}$ & P. cuvieri/INPA 5050 \\
Mata da Bituba* & $52^{\circ} 38^{\prime} \mathrm{W}$ & \\
Monte Dourado & & \\
\hline
\end{tabular}

*Names used by local residents.

Constitutive heterochromatin was evidenced using the method described by Sumner (1972). The nucleolar organizer region (NOR) was located using the method described by Howell and Black (1980). The G band (GTG) was determined using the method described by Seabright (1971).

For the mounting of the karyotypes, banded chromosomes (G band) were organized in order of decreasing size and separated into groups by morphological type. Chromosome morphology was determined based on the position of the centromere using the method described by Levan et al. (1964). In the determination of the number of arms [fundamental number (FN)], metacentric (m), submetacentic ( $\mathrm{sm}$ ) and subtelocentric (st) autosomes were considered to have two arms and acrocentric (a) autosomes were considered to have one arm.

\section{RESULTS}

Specimens were assigned to four groups (Patton, 1987) based on morphological characters of the cranium and baculum, diploid number and provenance data. Using the diploid number alone, the specimens were allocated to three groups: $2 n=28$ (two species), $2 n=38$ and $2 n=40$.

\section{Proechimys gr. longicaudatus}

Individuals with 28 chromosomes from the region of the mid-Madeira River had $14 \mathrm{~m}+$ $4 \mathrm{sm}+2 \mathrm{st}+6 \mathrm{a}+\mathrm{XX} / \mathrm{XY}$ and $\mathrm{FN}=46$. The sex chromosomes were metacentric, with the $\mathrm{X}$ larger than the Y. Three chromosome pairs were significantly larger than the others (first metacentric pair, first acrocentric pair and the subtelocentric pair) (Figures 1a and 2a). The G band allowed the correct pairing of the majority of homologous chromosomes (Figures $1 \mathrm{c}$ and $2 \mathrm{c}$ ). The $\mathrm{G}$ band pattern 
of the four largest chromosome pairs and the pair with the NOR were identical in all individuals. The NOR was located interstitially in the long arm of the second submetacentric pair (pair 9), coinciding with a secondary constriction visible with conventional staining. Five individuals from the right bank of the Aripuanã River (mid-Madeira River) exhibited heteromorphism in the size of the NOR in one of the homologues (duplication of NOR site), which was not found in the individuals from the left bank of the Aripuanã River and suggests two cytotypes: A (Figure 1b) and B (Figure $2 b)$. The pattern of constitutive heterochromatin also separated the individuals into two cytotypes. Cytotype A (4 males and 1 female) was characterized by exhibiting pericentromeric heterochromatic blocks in three metacentric pairs $(5,6,7)$, the pair with the NOR (9), three acrocentric pairs (11, 12 and 13), and on the $\mathrm{X}$ and $\mathrm{Y}$ chromosomes. In addition to the pericentromeric labeling, there was also a small band in the proximal region of the $\mathrm{X}$ chromosome (Figure 1d). Cytotype B (4 males and 1 female) was characterized by exhibiting strongly labeled heterochromatic blocks in the pericentromeric region of all chromosomes, including the sex chromosomes (Figure 2d).

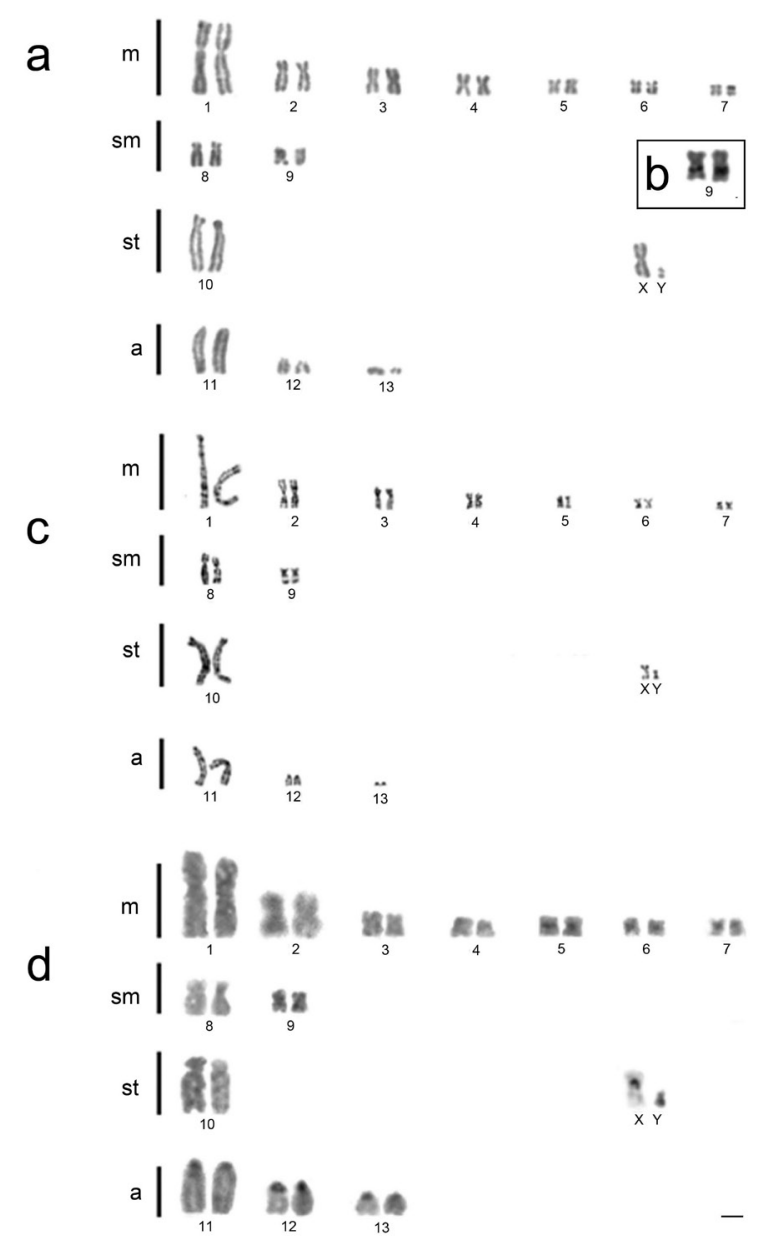

Figure 1. Karyotype characteristics of Proechimys gr. longicaudatus $(2 \mathrm{n}=28)$ - cytotype A. a. Conventional staining; b. NOR (chromosomes with greater amplification); c. G band; d. C band. 


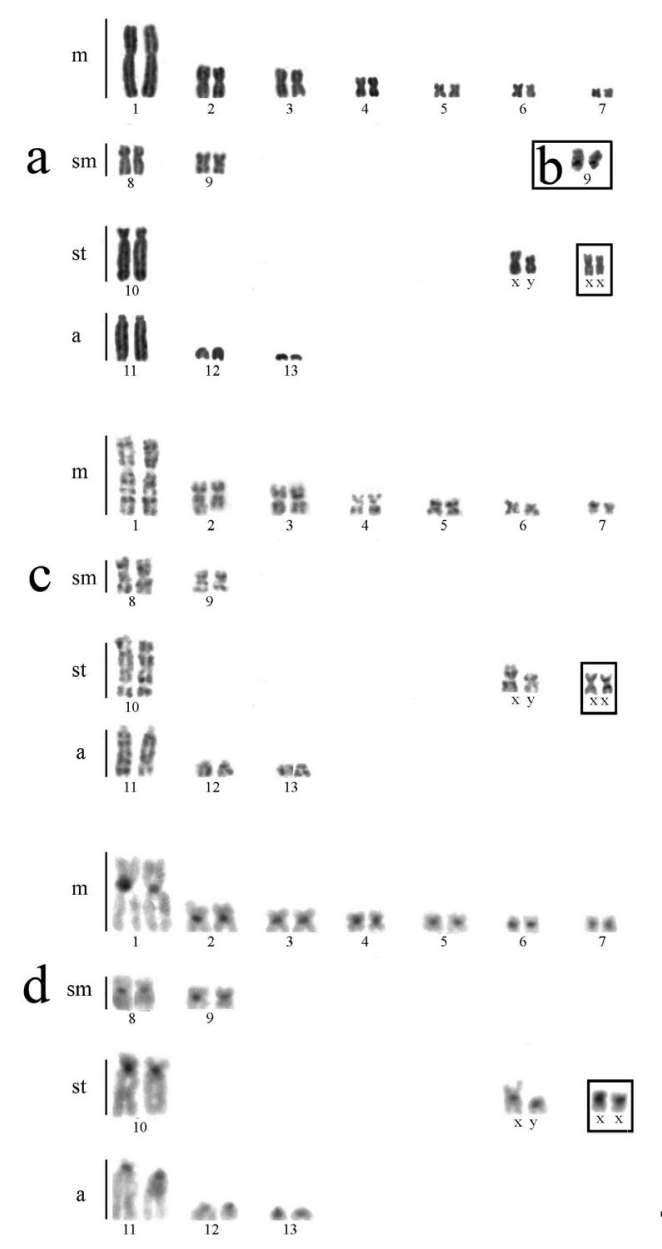

Figure 2. Karyotype characteristics of Proechimys gr. longicaudatus $(2 \mathrm{n}=28)$ - cytotype A. a. Conventional staining; b. NOR; c. G band; d. C band. Highlight $=$ sex chromosomes of opposite sex.

\section{Proechimys cuvieri}

The only individual (female) with 28 chromosomes in the Jari River Valley had $14 \mathrm{~m}+4 \mathrm{sm}+2 \mathrm{st}+6 \mathrm{a}+\mathrm{XX} / \mathrm{XY}$ and $\mathrm{FN}=46$. The $\mathrm{X}$ chromosome was metacentric. Three chromosome pairs were significantly larger than the others: the first metacentric pair, the first acrocentric pair and the subtelocentric pair (Figure 3a). G banding allowed the correct pairing of the majority of homologous chromosomes (Figure 3c) and also aided in the determination of the sex chromosomes. The NOR was located interstitially in the long arm of the second submetacentric pair (pair 9), which was in a region with secondary constriction (Figure $3 \mathrm{~b}$ ). The constitutive heterochromatin pattern exhibited pericentromeric heterochromatic blocks in three metacentric pairs $(5,6,7)$, the pair with the NOR (9), three acrocentric pairs $(11,12,13)$, and the X chromosome. Along with the pericentromeric 
labeling of the $\mathrm{X}$ chromosome, one of the homologues also exhibited a small band in the proximal region (Figure 3d).

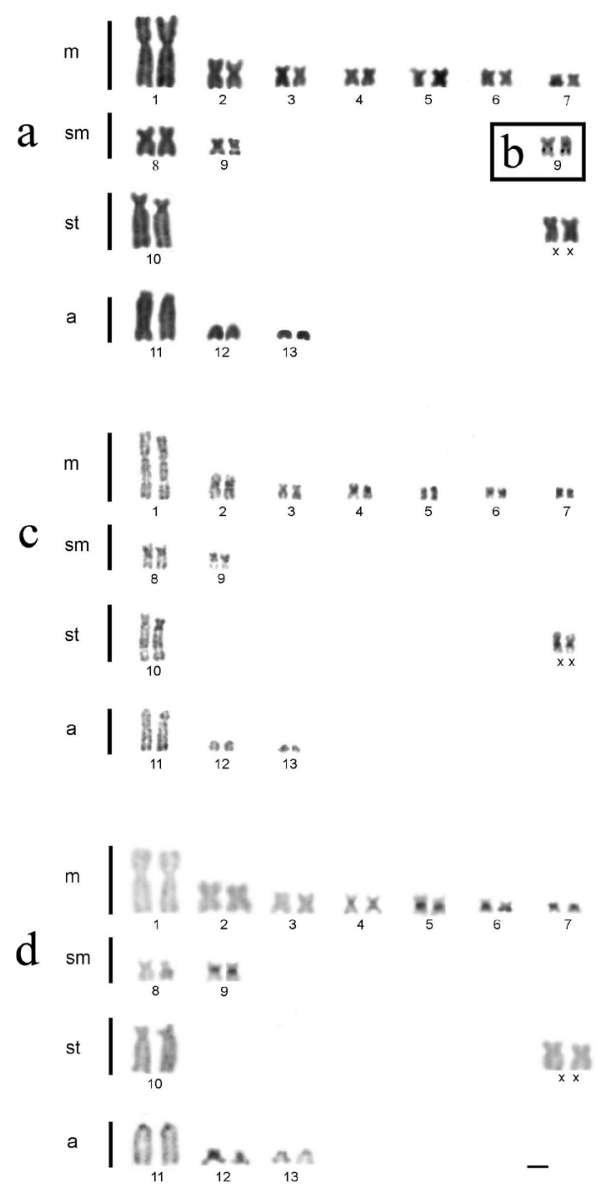

Figure 3. Karyotype characteristics of Proechimys cuvieri $(2 \mathrm{n}=28)$. a. Conventional staining; b. NOR; c. $\mathrm{G}$ band; d. $\mathrm{C}$ band.

\section{Proechimys gr. guyannensis}

The individuals with 38 chromosomes ( 4 males and 2 females) from the Jari River Valley had $6 \mathrm{~m}+4 \mathrm{sm}+6 \mathrm{st}+20 \mathrm{a}+\mathrm{XX} / \mathrm{XY}$ and $\mathrm{FN}=52$. The $\mathrm{X}$ chromosome was subtelocentric and the $Y$ was a small acrocentric chromosome. The three subtelomeric pairs were significantly larger than the other chromosomes of the complement (Figure 4a). $\mathrm{G}$ banding allowed the precise pairing of all homologues (Figure 4c). The NOR was located interstitially in the long arm of the second submetacentric pair (pair 5) in a region with secondary constriction (Figure 4b). The constitutive heterochromatin was exhibited with faint labeling in the pericentric region of the majority of chromosomes, including the $\mathrm{X}$ chromosome. The subtelocentric chromosomes had no labeling. The Y chromosome was completely heterochromatic (Figure 4d). 


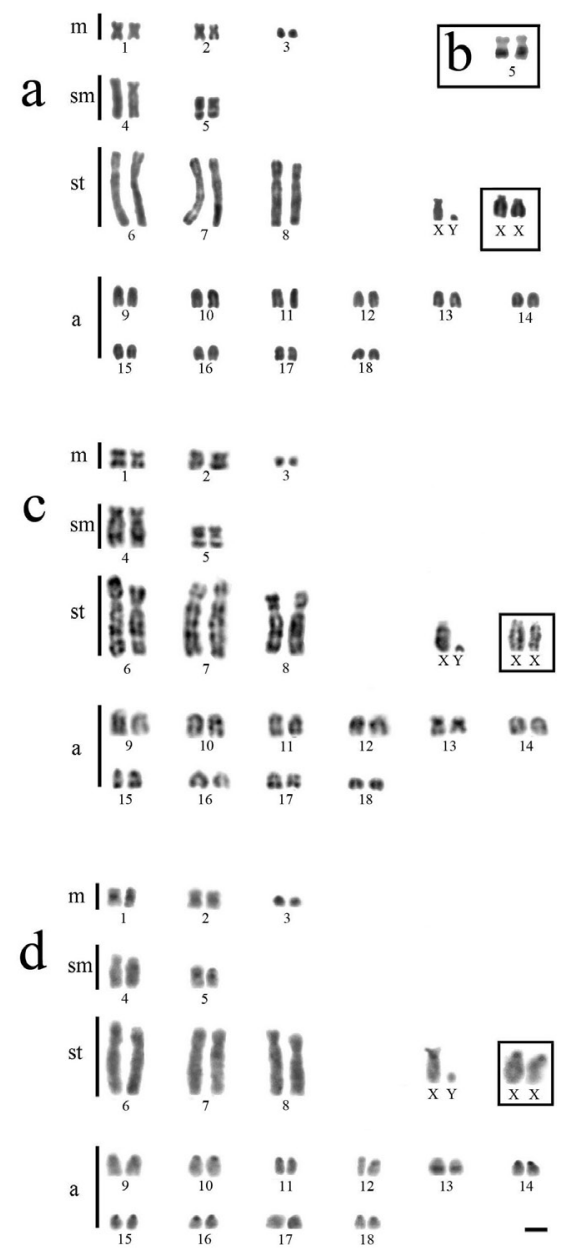

Figure 4. Karyotype characteristics of Proechimys gr. guyannensis $(2 \mathrm{n}=38)$. a. Conventional staining; b. NOR; c. $\mathrm{G}$ band; $\mathbf{d}$. $\mathrm{C}$ band. Highlight $=$ sex chromosomes of opposite sex.

\section{Proechimys gardneri}

The individuals with 40 chromosomes from the left bank of the Madeira River had $12 \mathrm{~m}+4 \mathrm{sm}+22 \mathrm{a}+\mathrm{XX} / \mathrm{XY}$ and $\mathrm{FN}=54$. The $\mathrm{X}$ and $\mathrm{Y}$ chromosomes were acrocentric and of medium and small sizes, respectively, in relation to the other chromosomes of the complement. Pairs 1 and 2 (m), 7 (sm), 9, 10, and 11 (a) were significantly larger than other chromosomes with the same morphology (Figure 5a). G banding allowed the correct pairing of the homologues and aided in the determination of the sex chromosomes (Figure 5c). The NOR was located interstitially in the long arm of the second submetacentric pair (pair 8) (Figure 5b). The constitutive heterochromatin pattern exhibited conspicuous blocks in the pericentromeric region of pairs 3, 4, 5, 6, 9, and 19 (all acrocentric) and on the $\mathrm{X}$ chromosome, where as the $\mathrm{Y}$ chromosome exhibited no labeling (Figure 5d). 


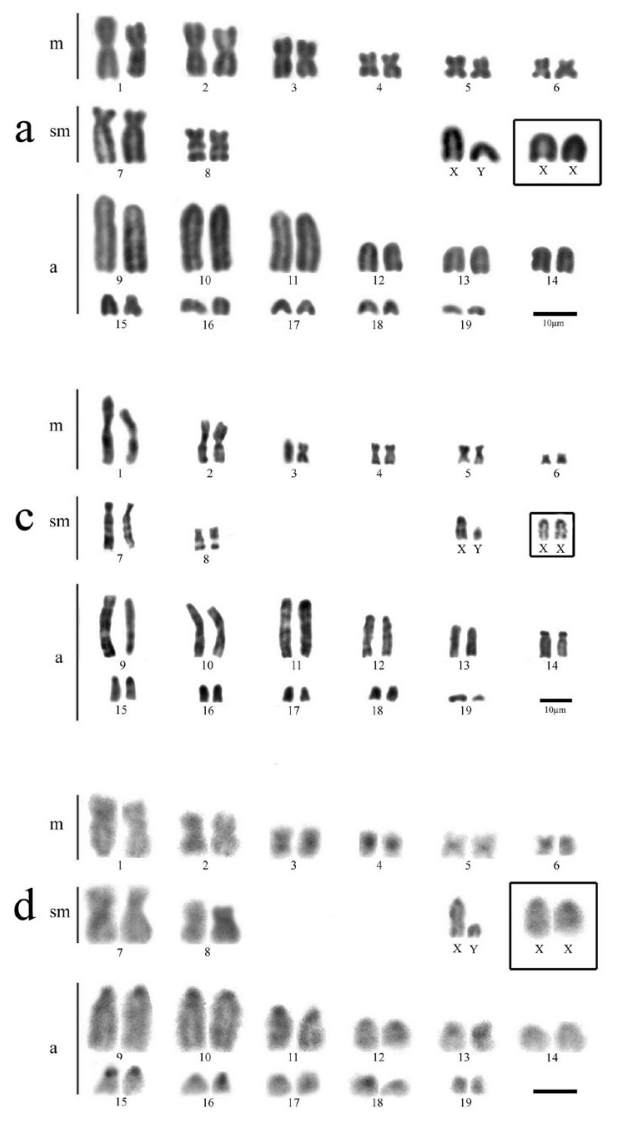

Figure 5. Karyotype characteristics of Proechimys gardneri $(2 n=40)$. a. Conventional staining; b. NOR; c. G band; $\mathbf{d}$. $\mathrm{C}$ band. Highlight $=$ sex chromosomes of opposite sex.

\section{DISCUSSION}

Karyological studies on Proechimys have been carried out since the early 1970s (Patton and Gardner, 1972). In a more recent cytogenetic revision of the genus, 52 karyotype forms were identified, with a diploid number ranging from 14 to 62 chromosomes (Weksler et al., 2001). In a compilation of chromosome data for Proechimys, including the present study, we found 61 karyotypic forms (Table 2) for the same 25 species listed in Wilson and Reeder (2005). Chromosome banding methods began to be employed in the late 1970s (Barros, 1978), but there are as yet very few studies on Proechimys involving these methods.

\section{Proechimys gr. longicaudatus and $P$. cuvieri $(2 \mathrm{n}=28)$}

A diploid number of 28 chromosomes has been reported for six species of Proechimys (P. longicaudatus, P. quadruplicatus, P. brevicauda, P. cuvieri, $P$. sp 1, and P. sp 3), with intraspecies and interspecies variations in the FN (Table 2). 
Table 2. Chromosome forms determined for the genus Proechimys compiled from the literature and revised, together with data from the present study.

\begin{tabular}{|c|c|c|c|c|}
\hline Group*/Species & $2 n$ & NF & Locality & Reference \\
\hline \multicolumn{5}{|l|}{ guyannensis } \\
\hline P. roberti (oris) & 30 & 56 & Curuá-Una and Primavera (Pará, Brazil) & 10,16 \\
\hline P. roberti & 30 & $54-55$ & Goiás, Tocantins, Maranhão (Brazil) & 26 \\
\hline P. roberti & 30 & 56 & $\begin{array}{l}\text { Uruçuí-Una (Piuí, Brazil); Paranã, Peixe (Tocantins, Brazil); } \\
\text { Cláudia, Gaucha do Norte, Vila Rica (Mato Grosso, Brazil) }\end{array}$ & 17 \\
\hline P. cherriei & 40 & 54 & Cairara del Orinoco, Venezuela & 23 \\
\hline Proechimys sp A & 38 & 52 & Barcelos and Santa Isabel (Amazonas, Brazil) & 4 \\
\hline Proechimys gr. guyannensis & 38 & 52 & Jari River Valley (Pará, Brazil) & This study \\
\hline P. guyannensis & 40 & 54 & Cayenne and Saül, French Guyana & 24 \\
\hline P. guyannensis & 40 & 56 & Balta, Peru & 20 \\
\hline P. guyannensis & 46 & 50 & Usina Hidrelétrica de Balbina (Uatumã River) & 27 \\
\hline $\begin{array}{l}\text { Proechimys sp B } \\
\text { goeldii }\end{array}$ & 46 & 50 & São João da Baliza (Roraima, Brazil) & 4 \\
\hline P. goeldii & 24 & 42 & Xingu River (Pará, Brazil) & 21 \\
\hline P. steerei & 24 & $40-42$ & Juruá River (Amazonas, Brazil) & 21 \\
\hline P. steerei & 24 & 42 & Pucallpa, Loreto and Balta (Peru) & $10,20,23$ \\
\hline P. cf. steerei & 24 & 44 & Ucayali, Peru & 2 \\
\hline P. amphichoricus & 26 & 44 & Território Federal Amazonas, Venezuela & 23 \\
\hline P. quadruplicatus & 28 & 44 & Limoncocha (Napo, Ecuador) & 10 \\
\hline P. quadruplicatus & 28 & 42 & $\begin{array}{l}\text { La Poza (Santiago, Peru); Lago Meduiním, } \\
\text { Amazonas (Brazil) }\end{array}$ & $4,10,21$ \\
\hline \multicolumn{5}{|l|}{ longicaudatus } \\
\hline P. longicaudatus & 28 & 46 & right bank of mid-Madeira River (Brazil) & This study \\
\hline \multirow[t]{2}{*}{ P. longicaudatus } & 28 & 48 & Jamari River (Rondônia, Brazil), Juruena and & \\
\hline & & & Aripuanã (Mato Grosso, Brazil) & 16,17 \\
\hline \multirow[t]{2}{*}{ P. longicaudatus } & 28 & 50 & Apiacás (Mato Grosso, Brazil), & \\
\hline & & & Parque Nacional das Emas (Goiás, Brazil) & 17,25 \\
\hline P. brevicauda & 28 & 48 & Juruá River, Acre (Brazil) & 21 \\
\hline P. brevicauda & 28 & 48 & Tambopata River (Madre de Dios, Peru) & 10 \\
\hline P. brevicauda (longicaudatus) & 28 & 50 & Tingo María (Peru) & $10,19,20$ \\
\hline P. brevicauda (longicaudatus) & 28 & 50 & Balta (Peru) & $10,19,20$ \\
\hline P. brevicauda (longicaudatus) & 28 & 50 & Curanja River (Ucayali, Peru) & $10,19,20$ \\
\hline P. brevicauda & 30 & 48 & Cenepa River (Amazonas, Peru) & 10 \\
\hline P. gularis & 30 & 48 & Limoncocha (Napo, Ecuador) & 10 \\
\hline Proechimys sp 1 & 28 & $51-52$ & Ucayali (Peru) & 2 \\
\hline Proechimys sp 2 & 30 & 50 & Ucayali (Peru) & 2 \\
\hline Proechimys sp 3 & 28 & $51-52$ & Loreto (Peru) & 2 \\
\hline Proechimys sp 4 & 34 & 56 & Loreto (Peru) & 2 \\
\hline $\begin{array}{l}\text { Proechimys gr. longicaudatus } \\
\text { simonsi }\end{array}$ & 30 & 52 & Jamari River (Rondônia, Brazil) & 16 \\
\hline P. simonsii (hendeei) & 32 & 58 & Balta (Peru); Putumayo (Colombia) & 20,23 \\
\hline P. simonsii & 32 & 58 & Ecuador and south of Peru & 10 \\
\hline $\begin{array}{l}\text { P. cf. simonsii } \\
\text { cuvieri }\end{array}$ & 32 & $57-58$ & Ucayali (Loreto, Peru) & 2 \\
\hline P. cuvieri & 28 & 46 & $\begin{array}{l}\text { Usina Hidrelétrica de Balbina (Uatumã River), } \\
\text { Macaco (Jaú River); Manaus and Cuieiras River; } \\
\text { Jari River Valley (Brazil) }\end{array}$ & $18,21,27$, This study \\
\hline P. cuvieri & 28 & 48 & Altamira (Pará, Brazil) & 21 \\
\hline $\begin{array}{l}\text { P. cuvieri } \\
\text { trinitatis }\end{array}$ & 28 & 50 & Cayenne (French Guyana); Acre (Brazil) & 21,24 \\
\hline P. poliopus & 42 & 72 & Táchira, Zulia, Merida (Venezuela) & 23 \\
\hline P. poliopus & 42 & 76 & Kasmera, Los Andes del Tucuco (Venezuela) & 1 \\
\hline P. guairae & $44-50$ & 72 & Aragua (Venezuela) & 22 \\
\hline P. guairae & $46-52$ & $72-74$ & $\begin{array}{l}\text { El Limon Turimo, Palmero, Turém, Cueva de Agua e } \\
\text { San Juan de Areo (Venezuela) }\end{array}$ & 1 \\
\hline P. guairae & 46 & 68 & Aragua, Carabobo, Falcon (Venezuela) & 23 \\
\hline P. guairae & 46 & 70 & Ocumare, Aragua (Venezuela) & 11 \\
\hline P. mincae & 48 & 68 & Minca, Magdalena (Colombia) & 10 \\
\hline P. guairae spp & 50 & 66 & Cojedes, Portuguesa (Venezuela) & 23 \\
\hline P. trinitatis & 62 & 80 & Cueva del Guacharo (Venezuela) & 1 \\
\hline P. trinitatis (P. urichi) & 62 & 76 & Monagas (Venezuela) & 23 \\
\hline
\end{tabular}

Continued on next page 


\begin{tabular}{|c|c|c|c|c|}
\hline Group*/Species & $2 n$ & NF & Locality & Reference \\
\hline P. urichi (Proechimys sp) & 62 & 66 & Barinas (Venezuela) & 23 \\
\hline Proechimys sp semispinosus & 62 & 74 & Guaquitas, Tierra Buena Las Matas, La Nulita (Venezuela) & 1 \\
\hline P. semispinosus & 30 & 50 & Ilha Gorgona, Choco (Colombia) & 5,12 \\
\hline P. semispinosus & 30 & 52 & Santa Rosa (Ecuador) & 10 \\
\hline P. semispinosus & 30 & $50-54$ & $\begin{array}{l}\text { Limón (Costa Rica); Canal Zone (Panama); } \\
\text { Valle (Colombia); Esmeraldas and El Oro (Ecuador) }\end{array}$ & 10,20 \\
\hline P. semispinosus & 30 & 54 & Cariari (Costa Rica) & 20 \\
\hline $\begin{array}{l}\text { P. oconnelli } \\
\text { canicollis }\end{array}$ & 32 & 52 & Meta (Colombia) & 10 \\
\hline $\begin{array}{l}\text { P. canicollis } \\
\text { decumanus }\end{array}$ & 24 & 44 & Bonda, Magdalena (Colombia); Cachiri River (Venezuela) & 1,10 \\
\hline $\begin{array}{l}P . \text { decumanus } \\
\text { Not certain }\end{array}$ & 30 & 54 & Aguas Verdes, Tumbes (Peru); Guayas, El Oro (Ecuador) & 10 \\
\hline P. pattoni ${ }^{+}$ & 40 & 56 & $\begin{array}{l}\text { Upper Juruá River (Acre, Brazil); Ucayali, Madre de Dios, } \\
\text { Puno, Balta, Loreto (Peru) }\end{array}$ & $7,20,19$ \\
\hline P. gardneri & 40 & 54 & left bank of mid Madeira River (Amazonas, Brazil) & This study \\
\hline P. gardneri & 40 & 56 & $\begin{array}{l}\text { Juruá River (Amazonas, Brazil); Abuna and General } \\
\text { Frederico Roman (Bolivia) }\end{array}$ & 7 \\
\hline P. echinothrix & 32 & 60 & Juruá River (Amazonas, Brazil) & 7 \\
\hline P. kulinae & 34 & 52 & Juruá River (Amazonas, Brazil) & 7 \\
\hline Proechimys sp 5 & $14-16$ & 18 & Amazonas (Brazil) & 3 \\
\hline Proechimys sp 6 & 30 & 52 & Jamari River (Rondônia, Brazil) & 16 \\
\hline Proechimys sp 7 & 32 & 54 & Boyacá (Colombia) & 6 \\
\hline Proechimys sp 8 & 44 & 52 & Acampamento Cabo Frio (Amazonas, Brazil) & 16 \\
\hline
\end{tabular}

$2 \mathrm{n}=$ diploid number; $\mathrm{FN}=$ number of arms; between parentheses = names in the original literature; *Groups sensu Patton 1987 (modified from Weksler et al., 2001). ${ }^{+}$Patton and Gardner (1972) refer to specimens from Balta, Peru, such as $P$. guyannensis, whereas Patton (1987) denominated them Proechimys sp, temporarily including them in the cuvieri group. In 1998, Silva included the Balta specimens in the new species $P$. pattoni. Considering the morphological differences and the inexistence of molecular evidence associating this species to any of the groups of Proechimys defined by Patton (1987), the option was made to not determine the group to which $P$. pattoni would be associated. $1=$ Aguilera and Corti, 1994; 2 =Aniskin, 1994; 3 = Barros, 1978; 4 = Bonvicino et al., 2005; 5 = Bueno and Gomez-Laverde, 1993; 6 = Bueno et al., 1989; 7 = da Silva, 1998; $8=$ Emmons, 1982; $9=$ Emmons and Feer, 1997; $10=$ Gardner and Emmons, 1984; $11=$ George and Weir, 1973; 12 = Gomez-Laverde et al., 1990; 13 = King, 1993; 14 = Lara et al., 1996; 15 = Lara and Patton, 2000; 16 = Leal-Mesquita, 1991; 17 = Machado et al., 2005; $18=$ Maia and Langguth, 1993; $19=$ Patton, 1987; $20=$ Patton and Gardner, 1972; 21 = Patton et al., 2000; 22 = Reig, 1989; 23 = Reig and Useche, 1976; 24 = Reig et al., 1979; 25 = Rodrigues et al., 2002; 26 = Weksler et al., 2001; 27 = da Silva et al., 2001.

Chromosomally, P. cuvieri from the Jari River Valley resembles P. cuvieri from the region of the Uatumã River, differing in the nomenclature of the largest chromosome pair (Maia and Langguth, 1993) and the morphology of the sex chromosomes, as the $\mathrm{X}$ and $\mathrm{Y}$ chromosomes are acrocentric in P. cuvieri from the Uatumã region and metacentric in the Jari region, with the $\mathrm{X}$ larger than the $\mathrm{Y}$ chromosome in both cases. It is possible that this differentiation is due to pericentric inversion chromosome rearrangements. Thus, even with the autosomal complements of these two populations being equal, the differences found in the sex chromosomes and C-band pattern are sufficient traits for suggesting that they represent distinct evolutionary units and as such two different species. The Jari karyotype is reported here for the first time for the genus.

Patton (1987) considered the P. cuvieri group monotypic, although he pointed out the distinctiveness of specimens from Balta, Peru [these specimens were referred to by Patton and Gardner (1972) as P. guyannensis, and later, were assigned to P. pattoni by da Silva (1998)]. However, at least three karyotypic forms have been described for $P$. cuvieri, all with $2 \mathrm{n}=$ 28 chromosomes, but with the FN varying from 46 (Maia and Langguth, 1993; Patton et al., 
2000; present study), 48 (Patton et al., 2000) to 50 (Reig et al., 1979; Patton et al., 2000). This suggests that $P$. cuvieri may be a species complex.

For $P$. gr. longicaudatus, this is also the first record of a population with 28 chromosomes and $\mathrm{FN}=46$. Three other cytotypes with this same diploid number have been reported for the regions of the upper Madeira River and the State of Goiás, with variation in FN (48-50) and morphology of the sex chromosomes (a medium-size submetacentric $\mathrm{X}$ and small acrocentric $\mathrm{Y}$ in individuals from the upper Madeira; acrocentric $\mathrm{X}$ and $\mathrm{Y}$, with the $\mathrm{X}$ larger than the $\mathrm{Y}$ in populations in Goiás, and metacentric $\mathrm{X}$ and $\mathrm{Y}$ chromosomes, with the $\mathrm{X}$ larger than the $\mathrm{Y}$ in the region of the mid-Madeira River). It is possible that pericentric inversions gave rise to this chromosome diversity, but in an independent fashion on the $\mathrm{X}$ and $\mathrm{Y}$ chromosomes.

Considering the geographic distribution proposed for $P$. gr. longicaudatus by Patton, 1987, the data described by Machado et al. (2005) and the provenance of our samples, the eastern geographic limit of the P. longicaudatus group extends to the right bank of the Aripuanã River and the State of Goiás to the southeast (Figure 6).

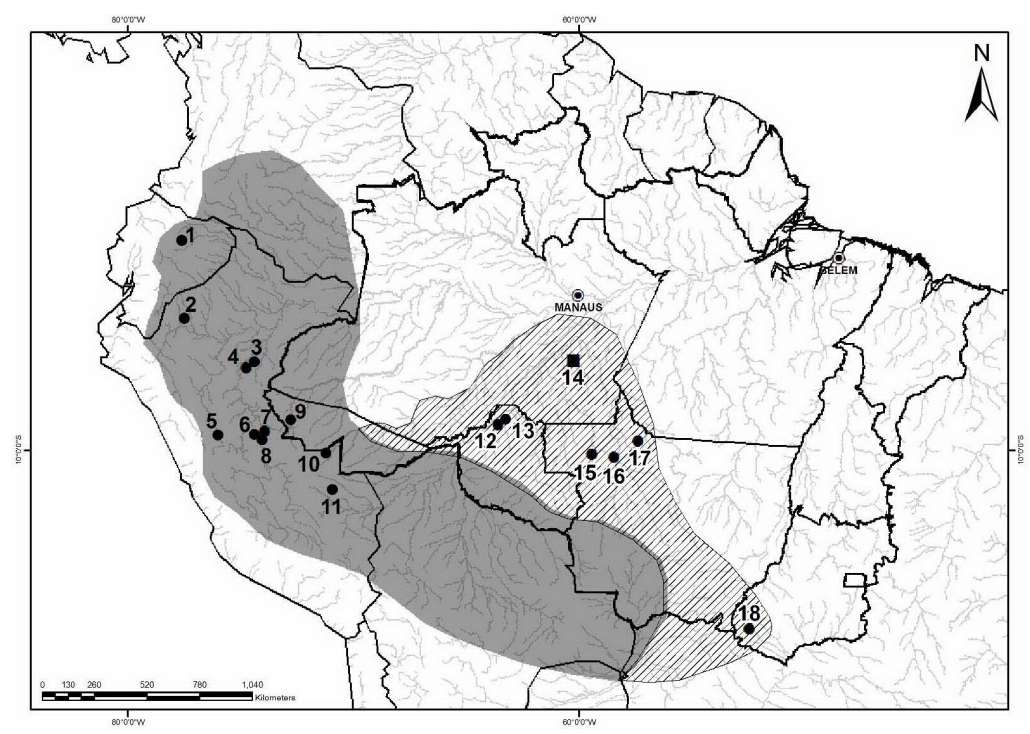

Figure 6. Distribution map of karyotype forms of the longicaudatus group. Dark area denotes geographic distribution proposed for group (Patton, 1987); crosshatched area denotes proposed broadening of distribution. 1 = Proechimys gularis $\left(2 \mathrm{n}=30, \mathrm{NF}_{\mathrm{A}}=48\right)$ Napo, Equador (Gardner and Emmons, 1984); $2=$ P. brevicauda $\left(2 \mathrm{n}=30, \mathrm{NF}_{\mathrm{A}}=48\right)$ Cenepa River, Peru (Gardner and Emmons, 1984); $3=$ Proechimys sp $3\left(2 \mathrm{n}=28, \mathrm{NF}_{\mathrm{A}}=51-52\right)$ Loreto, Peru (Aniskin, 1994); $4=$ Proechimys sp $4\left(2 \mathrm{n}=34, \mathrm{NF}_{\mathrm{A}}=56\right)$ Loreto, Peru (Aniskin, 1994); $5=$ P. brevicauda $\left(2 \mathrm{n}=28, \mathrm{NF}_{\mathrm{A}}=50\right)$ Tingo María, Peru (Gardner and Emmons, 1984; Patton, 1987; Patton and Gardner, 1972); $6=$ P. brevicauda $\left(2 \mathrm{n}=28, \mathrm{NF}_{\mathrm{A}}=50\right)$ Curanja River, Ucayali, Peru (Gardner and Emmons, 1984; Patton, 1987; Patton and Gardner, 1972); 7 = Proechimys sp $1(2 \mathrm{n}=$ $\left.28, \mathrm{NF}_{\mathrm{A}}=51-52\right)$ Ucayali, Peru (Aniskin, 1994); 8 = Proechimys sp $2\left(2 \mathrm{n}=30, \mathrm{NF}_{\mathrm{A}}=50\right)$, Ucayali, Peru (Aniskin, 1994); $9=$ P. brevicauda $\left(2 \mathrm{n}=28, \mathrm{NF}_{\mathrm{A}}=48\right)$ Juruá River, Acre, Brazil (Patton et al., 2000); 10 $=$ P. brevicauda $\left(2 \mathrm{n}=28, \mathrm{NF}_{\mathrm{A}}=\right.$ 50) Balta, Peru (Gardner and Emmons, 1984; Patton, 1987; Patton and Gardner, 1972); $11=$ P. brevicauda $\left(2 \mathrm{n}=28, \mathrm{NF}_{\mathrm{A}}\right.$ =48), Tambopata River, Madre de Dios, Peru (Gardner and Emmons, 1984); $12=$ P. longicaudatus $\left(2 \mathrm{n}=28, \mathrm{NF}_{\mathrm{A}}=48\right)$, Jamari River, Mato Grosso, Brazil (Leal-Mesquita, 1991; Machado et al., 2005); $13=P$. gr. longicaudatus $\left(2 \mathrm{n}=30, \mathrm{NF}_{\mathrm{A}}\right.$ $=52)$ Jamari River, Mato Grosso, Brazil (Leal-Mesquita, 1991); $14=P$. gr. longicaudatus $\left(2 \mathrm{n}=28, \mathrm{NF}_{\mathrm{A}}=46\right)$ right bank of Madeira River, Amazonas, Brazil (present study); 15 and $\mathbf{1 6}=$ P. longicaudatus $\left(2 \mathrm{n}=28, \mathrm{NF}_{\mathrm{A}}=48\right)$ Aripuanã $(15)$ and Juruena (16), Mato Grosso, Brazil (Machado et al., 2005); 17 and $\mathbf{1 8}=$ P. longicaudatus $\left(2 \mathrm{n}=28, \mathrm{NF}_{\mathrm{A}}=50\right)$ Apiacás, Mato Grosso (17) and Parque Nacional das Emas, Goiás (18), Brazil (Machado et al., 2005; Rodrigues et al., 2002). 


\section{Proechimys gr. guyannensis $(2 \mathrm{n}=38)$}

A diploid number of 38 chromosomes have been previously described for Proechimys sp A from the upper Negro River by Bonvicino et al. (2005). The karyotype described here for Proechimys gr. guyannensis is identical to that. However, these authors (op. cit.) classify the $\mathrm{X}$ chromosome as being acrocentric and of medium size, while we considered the $\mathrm{X}$ chromosome as subtelocentric and of medium size. A comparison of Figure 4 from this study and Figure 2 from Bonvicino et al. (2005) suggests a single karyotype, with a difference in chromosome classification.

Based on molecular evidence, Bonvicino et al. (2005) also associated animals with $2 n=38$ chromosomes from the upper Negro River to the guyannensis group (Patton, 1987). The distance separating the upper Negro site and the Jari region is gigantic $(1100 \mathrm{~km})$, and a more refined geographic sampling in the area between those sites is highly recommended in order to evaluate the specific status of these animals. Nevertheless, it is interesting to note that to date, $2 \mathrm{n}=38$ chromosomes in Proechimys are delimited by the Negro River to the west and by the Amazon River to the south (Figure 7).

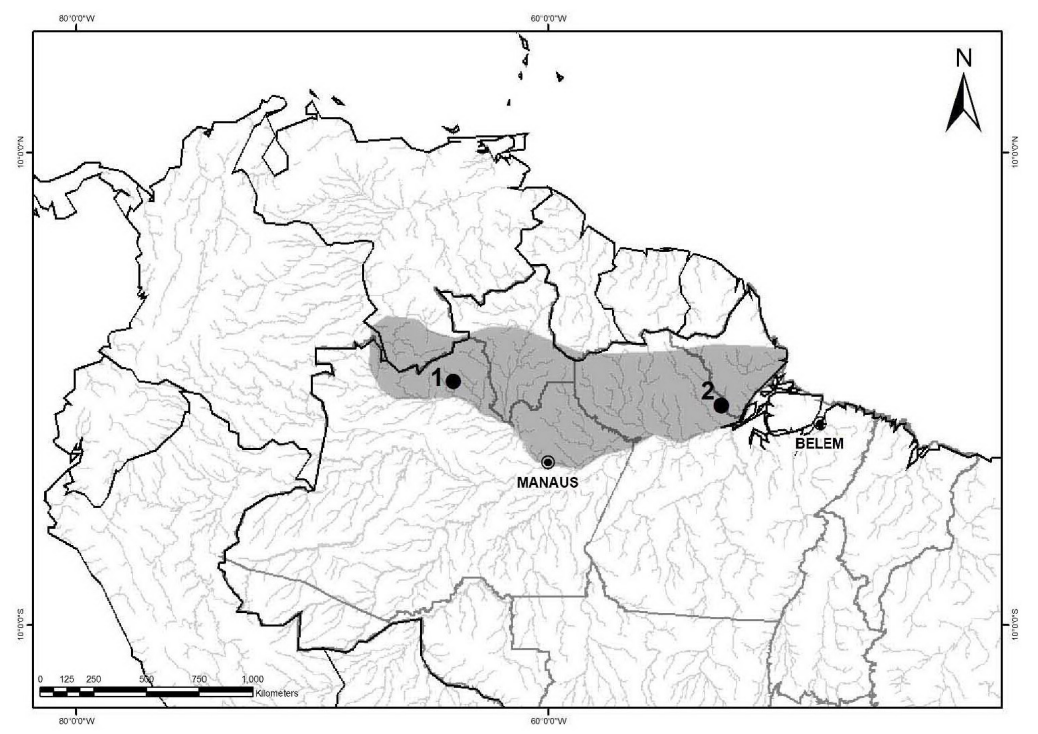

Figure 7. Map of locations of occurrence of Proechimys $(2 \mathrm{n}=38)$. Dark area denotes geographic distribution delimited by the Negro River (to the west) and Amazon River (to the south); $\mathbf{1}=$ Proechimys sp A, upper Negro River, State of Amazonas (Bonvicino et al., 2005); 2 = Proechimys gr. guyannensis, Jari River Valley, State of Pará (present study).

\section{Proechimys gardneri $(2 \mathrm{n}=40)$}

Individuals from the mid-Madeira River with a diploid number of 40 chromosomes are tentatively identified as $P$. gardneri based on morphological and cytogenetic characters, but relative to $P$. gardneri from the Juruá River, they are larger, more robust and have more rigid aristiform hair.

To date, there are four known species with a diploid number of 40 chromosomes: $P$. 
cherriei, $P$. guyannensis (both with $\mathrm{FN}=54$ ), $P$. pattoni and $P$. gardneri (both with $\mathrm{FN}=56$ ) (Table 2). Although the karyotype of $P$. gardneri from the Madeira River analyzed in the present study has the same diploid and fundamental numbers as $P$. guyannensis in French Guyana and $P$. cherriei in Venezuela (Reig and Useche, 1976; Reig et al., 1979), morphologically, their autosomal and sex chromosomes are more similar to those of $P$. gardneri and P. pattoni, both from the Juruá River. The sex chromosomes (X and $\mathrm{Y}$ ) in P. gardneri from the mid-Madeira River are acrocentric with the $\mathrm{X}$ larger than the $\mathrm{Y}$, while the $\mathrm{X}$ chromosome in the species from French Guyana and Venezuela with $\mathrm{FN}=54$ is subtelocentric.

Our study suggests that $P$. gardneri is more diverse than previously thought, with at least two different karyotypes within the group. Moreover, it also suggests a broader geographic distribution, possibly with the eastern limit at the Madeira River, with the Solimões River and a small stretch of the Amazon River (to the mouth of the Madeira River) as the northern limit (Figure 8).

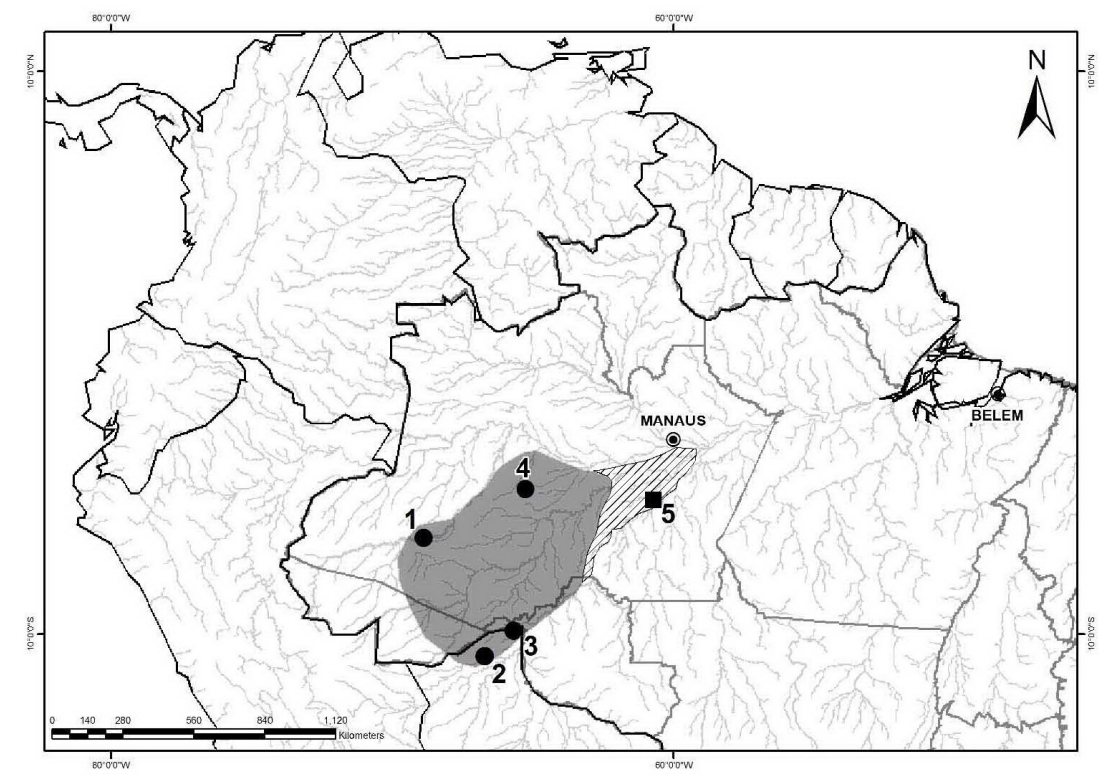

Figure 8. Distribution map of karyotype forms of Proechimys gardneri. Dark area denotes proposed distribution for the species (da Silva, 1998); crosshatched area denotes increase in the distribution proposed in present study; 1 = Altamira, Juruá River, Brazil (da Silva, 1998); 2 = Abuna Province, Bolivia (da Silva, 1998); 3 = General Federico Roman Province, Bolivia (da Silva, 1998); 4 = upper Urucu River, State of Amazonas, Brazil (da Silva, 1998); 5 = left bank of mid Madeira River, State of Amazonas, Brazil (present study).

\section{Chromosome banding in Proechimys}

G banding was employed to compare the two Proechimys gr. longicaudatus cytotypes found in the present study with patterns observed in species of Proechimys with $2 \mathrm{n}=28$ chromosomes reported in the literature (Machado et al., 2005; Bonvicino et al., 2005). For such, the largest chromosomes were used (chromosomes 1, 8, 9, 10, and 11) (Figures 4c and 5c), in which the band pattern had the greatest resolution and considerable homeology was found. For the remaining chromosomes of the complement, this comparison was not always precise due 
to the quality of the bands and/or degree of condensation of the chromosomes.

All studies on species of Proechimys report a single NOR system with labeling coinciding with a secondary constriction located in the distal region of the long arm of a mediumsize submetacentric pair (Yonenaga-Yassuda et al., 1985; Bueno et al., 1989; Gomez-Laverde et al., 1990; Leal-Mesquita, 1991; Maia and Langguth, 1993; Bueno and Gomez-Laverde, 1993; Machado et al., 2005). This pattern was also observed in the species we analyzed. However, the position of this pair in the karyotype is different between species (pair 8 in P. gardneri, pair 9 in P. cuvieri and P. gr. longicaudatus and pair 5 in Proechimys gr. guyannensis). This is due to Robertsonian and non-Robertsonian rearrangements that occurred in the evolutionary process in this genus, altering the karyotype formula of the species but not involving the nucleolar pair. Thus, although the nucleolar pair is homeologous for all species of Proechimys and the entire Echimyidae family (Yonenaga-Yassuda et al., 1985), its position in the karyotype may be a species-specific marker.

In the specimens of $P$. gr. longicaudatus from the right bank of the Aripuanã River (cytotype A), the nucleolar pair was heteromorphic, which may be due to a duplication of the ribosomal site in one of the homologues (Figure 4b) or an unequal crossing over. Within the family Echimyidae, Yonenaga-Yassuda et al. (1985) also reported a duplication of ribosomal sites in P. iheringi (currently elevated to the genus Trinomys) in the Atlantic Forest in the State of São Paulo. According to these authors (op. cit.), this size variation in the labeling was due to either a partial reduction or gain in rDNA genes. A similar variation has also been described for Trichomys apereoides (Yonenaga-Yassuda et al., 1985). Thus, this heteromorphism in the NOR may be a generic and/or population marker.

For $\mathrm{C}$ banding, data in the literature are limited to some Venezuelan species (Aguilera and Pérez-Zapata, 1991; Aguilera and Corti, 1994), two Colombian species (Bueno et al., 1989; Gomez-Laverde et al., 1990) and some Brazilian species (Barros, 1978; YonenagaYassuda et al., 1985; Leal-Mesquita, 1991; Maia and Langguth, 1993; Bonvicino et al., 2005; Machado et al., 2005). However, even with the few studies that employ $\mathrm{C}$ banding, different patterns have been described for Proechimys.

In general, heterochromatic blocks are found in the centromeric regions of all (or at least the majority) chromosomes and, in some cases, interstitial labeling is also seen, especially on larger chromosomes. In the majority of species, the sex chromosomes also exhibit heterochromatic blocks in the centromeric region and the $\mathrm{Y}$ chromosome is, at times, completely heterochromatic (Maia and Langguth, 1993; Machado et al., 2005). With less frequency, patterns are detected in which the pericentromeric region of only some chromosomes is labeled (Gomez-Laverde et al., 1990; Machado et al., 2005). It should be stressed that these patterns generally vary between populations and the intensity of the labeling may often be differentiated between strong and faint.

Two C-band patterns were evident among the four species we analyzed: one in which all the chromosomes exhibited heterochromatic blocks in the centromeric region $(P$. gr. longicaudatus - cytotype B) and another in which only some chromosomes exhibited centromeric heterochromatic blocks ( $P$. gr. longicaudatus - cytotype A, P. cuvieri, P. gardneri and Proechimys gr. guyannensis). However, the number and type of chromosome with heterochromatic labeling was variable in the second pattern.

The X chromosome in all species studied had heterochromatic blocks in the centromeric region, whereas the $\mathrm{Y}$ chromosome that had centromeric blocks in $P$. gr. longicaudatus (both 
cytotypes) and P. cuvieri was completely heterochromatic in Proechimys gr. guyannensis and had no labeling in $P$. gardneri. Thus, the Y chromosome can be considered a marker for species of the genus Proechimys from the morphological standpoint and with regard to the C-band pattern.

For $P$. gr. longicaudatus, different constitutive heterochromatin distribution patterns have been described for populations in the States of Rondônia and Goiás and the northern portion of the State of Mato Grosso (Machado et al., 2005). These authors report that three of these populations [Samuel Hydroelectric Plant (Rondônia), Aripuanã and Juruena (Mato Grosso)] exhibit all or nearly all chromosomes with heterochromatic blocks in the centromeric region, which is similar to the pattern described for $P$. gr. longicaudatus - cytotype B in the present study. However, the labeling of the sex chromosomes differs between these populations. The pattern in P. gr. longicaudatus - cytotype A was different from all the others, with centromeric labeling in only 16 chromosomes.

An alteration in the amount and distribution of heterochromatin has been considered one of the most common forms of chromosome evolution in mammals (Baker et al., 1987), as it influences the pairing of the homologues in mutation events and gene recombination events and consequently affects the speciation process (Robbins and Baker, 1981). Specifically for $P$. gr. longicaudatus analyzed in the present study, the $\mathrm{C}$ band and NOR data allow considering the two cytotypes from the region of the mid-Madeira River as two evolutionary units, different from P. longicaudatus from the upper Maderia River (Machado et al., 2005).

Considering the existing taxonomic instability of Proechimys, a simple comparison of the chromosome data obtained here with those available in the literature becomes a difficult task. Due to the lack of a clear species taxonomic composition for the genus, the synonymization of taxa may still be necessary There is also considerable overlap in the diploid number among different species, such as $P$. pattoni and $P$. gardneri from the region of the Juruá River, both with $2 \mathrm{n}=40$ chromosomes and FN $=56$ (da Silva, 1998), but in this case species recognition was supported by morphological and molecular data. Moreover, what is currently considered a single species may have more than one karyotype form, such as in P. cuvieri, with $2 \mathrm{n}=$ 28 chromosomes. But with some populations in the central and western Amazon with FN $=46$ (this study; Patton et al., 2000) and others in French Guyana and the central Amazon in Brazil with $\mathrm{FN}=50$ (Reig et al., 1979; Maia and Langguth, 1993) the true nature of this variation still needs to be ascertained.

In addition, there is yet no robust phylogeny for Proechimys in which phylogenetic relationships among species are well established, thus preventing any deeper analysis of chromosome evolution of this genus. da Silva (1998) presents the first molecular phylogeny for Proechimys based on the mitochondrial gene cytochrome b. Although it supported the differentiation of the 13 taxa analyzed, there was no support for the deeper nodes of the tree and to date the phylogenetic relationships among species remain unclear. The clarification of all these questions largely depends on a more refined geographic sampling and comprehensive taxonomic revision of the genus, including ecological, morphological, genetic, karyologic data of available and new materials.

The cytogenetic data presented also demonstrate that chromosome banding is indispensible to cytogenetic studies of Proechimys, as such methods allow the identification of genetically distinct populations and make the analysis more accurate. We also propose that for this group of rodents, unlike normally done for other mammals, that chromosomes should be organized in order of decreasing size within each morphological group (metacentric, submetacentric, subtelocentric and acrocentric, as proposed by Levan et al., 1964) as has been 
presented in the earlier studies of Proechimys cytogenetics (Reig and Useche, 1976; Reig et al., 1979; Patton et al., 2000). This would greatly facilitate the detection and comparison of subtler differences among karyotypes within Proechimys.

\section{ACKNOWLEDGMENTS}

We thank J.L. Patton for his comments, M.C. Gross, C.H. Schneider and M.L. Terencio for laboratory assistance and T.N. Kuck for drawing the maps. Research supported by the Brazilian Science and Research Council (CNPq), the UK Government Darwin Initiative, The State of Amazonas Research Foundation (FAPEAM), The International Institute of Education in Brazil (IEB), and the National Institute for Amazonian Research (INPA/MCT/Brazil). E.S. Eler received a study grant from CAPES through the graduate program in Genetics, Conservation and Evolutionary Biology (GCBEv/INPA).

\section{REFERENCES}

Aguilera M and Pérez-Zapata A (1991). Bandeo C en Especies de Proechimys (Rodentia) con Números Cromossómicos Extremos. Resúmenes XLI Convención Anual Asociación Venezolana para el Avance de la Ciencia ASOVAC, Caracas.

Aguilera M and Corti M (1994). Craniometric differentiation and chromosomal speciation of the genus Proechimys (Rodentia, Echimyidae). Z. Saügertierkund 59: 366-377.

Aniskin VM (1994). Evolutionary Cytogenetics of Spiny Rats from Peruvian Amazonia (Rodentia, Echimyidae). In: Mlekopitayushchie Peruanskoi Amazonii (Socolov VE, ed.). Nauka, Moscow, 62-82.

Baker RJ, Qumsiyeh MB and Hood CS (1987). Role of Chromosomal Banding Patterns in Understanding Mammalian Evolution. In: Current Mammalogy (Genoways HH, ed.). Vol. 1. Plenum Publication Corporation, New York, 67-96.

Barros RMS (1978). Variabilidade Cromossômica em Proechimys e Oryzomys (Rodentia) da Amazônia. Master's thesis, Instituto de Biociências, USP, São Paulo.

Bonvicino CR, Otazú IB and Vilela JF (2005). Karyologic and molecular analysis of Proechimys Allen, 1899 (Rodentia, Echimyidae) from the Amazonian region. Arq. Mus. Nac. Rio de Janeiro 63: 191-200.

Bueno ML and Gomez-Laverde M (1993). Variación heterocromática en Proechimys semispinosus (Rodentia: Echimyidae) de la región pacífica Colombiana. Caldasia 17: 333-340.

Bueno ML, Gomez-Laverde M and Morales A (1989). Caracterización cariológica de Proechimys sp (Rodentia: Echimyidae) de una colônia experimental. Biomedica 9: 13-22.

da Silva MNF (1998). Four New Species of Spiny Rats of the Genus Proechimys (Rodentia: Echimyidae) From the Western Amazon of Brasil. Proceedings of the Biological Society of Washington, Washington, 436-471.

da Silva MNF, Rylands AB and Patton JL (2001). Biogeografia e Conservação da Mastofauna na Floresta Amazônica Brasileira. In: Biodiversidade na Amazônia Brasileira: Avaliação e Ações Prioritárias para a Conservação, Uso Sustentável e Repartição de Benefícios (Capobianco JPR, Veríssimo A and Moreira A, eds.). Estação Liberdade, Instituto Socioambiental, São Paulo, 110-131.

Emmons LH (1982). Ecology of Proechimys (Rodentia, Echimyidae) in South Eastern Peru. J. Trop. Ecol. 23: 280-290.

Emmons LH and Feer F (1997). Neotropical Rainforest Mammals: A Field Guide. 2nd edn. The University of Chicago Press, Chicago.

Ford CE and Hamerton JL (1956). A colchicine, hypotonic citrate, squash sequence for mammalian chromosomes. Stain Technol. 31: 247-251.

Gardner AL and Emmons LH (1984). Species groups in Proechimys (Rodentia, Echimyidae) as indicated by karyology and bullar morphology. J. Mammal. 65: 10-25.

George W and Weir BJ (1973). A note on the karyotype of Proechimys guairae (Rodentia: Hystricomorpha). Mammalia 37: $330-332$

Gomez-Laverde M, Bueno ML and Cadena A (1990). Poblaciones de Ratas (Proechimys Semispinosus) (Rodentia: Echimyidae). In: Biota y Ecosistema de Gorgona y Gorgonilla (Aguirre J and Rangel O, eds.). Fundo Fen Colombia, Editorial Presencia, Bogotá, 244-251.

Howell WM and Black DA (1980). Controlled silver-staining of nucleolus organizer regions with a protective colloidal developer: a 1-step method. Experientia 36: 1014-1015. 
King M (1993). Species Evolution - The Role of Chromosome Change. Cambridge University Press, Cambridge.

Lara MC and Patton JL (2000). Evolutionary diversification of spiny rats (genus Trinomys, Rodentia: Echimyidae) in the Atlantic Forest of Brazil. Zool. J. Linnean Soc. 130: 661-686.

Lara MC, Patton JL and da Silva MN (1996). The simultaneous diversification of South American echimyid rodents (Hystricognathi) based on complete cytochrome b sequences. Mol. Phylogenet. Evol. 5: 403-413.

Leal-Mesquita ERRBP (1991). Estudos Citogenéticos em Dez Espécies de Roedores Brasileiros da Família Echimyidae. Master's thesis, Instituto de Biociências, USP, São Paulo.

Levan A, Fredga K and Sandberg AA (1964). Nomenclature for centromeric position on chromosomes. Hereditas 52: 201-220.

Machado T, Silva MJJ, Leal-Mesquita ER, Carmignotto AP, et al. (2005). Nine karyomorphs for spiny rats of the genus Proechimys (Echimyidae, Rodentia) from North and Central Brazil. Genet. Mol. Biol. 28: 682-692.

Maia V and Langguth A (1993). Constitutive heterochromatin polymorphism and NORs in Proechimys cuvieri Petter, 1978 (Rodentia, Echimyidae). Braz. J. Genet. 16: 145-154.

Moojen J (1948). Speciation in the Brazilian spiny rats (genus Proechimys, family Echimyidae). Univ. Kans. Publs. Mus. Nat. Hist. 1: 301-406.

Patton JL (1987). The Species Groups of Spiny Rats, Genus Proechimys (Rodentia, Echimyidae). In: Studies in Neotropical mammalogy. Essay in Honor of Philip Hershkovitz (Patterson BD and Timm RM, eds.). Field Museum of Natural History, Chicago, 305-345.

Patton JL and Gardner AL (1972). Notes on the Systematics of Proechimys (Rodentia: Echimyidae). In: With Emphasis on Peruvian Forms. Occasional Papers of the Museum of Zoology. Louisiana State University, Baton Rouge, 29-30.

Patton JL, da Silva MNF and Malcolm JR (2000). Mammals of the rio Juruá and the evolutionary and ecological diversification of Amazonia. Bull. Am. Mus. Nat. Hist. 244: 1-306.

Reig OA (1989). Karyotypic Repatterning as one Triggering Factor in Explosive Speciation. In: Evolutionary Biology of Transient Unstable Populations (Fondevila A, ed.). Springer-Verlag, Berlin, 246-289.

Reig OA and Useche M (1976). Diversidad cariotípica y sistemática en poblaciones venezolanas de Proechimys (Rodentia, Echimyidae), con datos adicionales sobre poblaciones de Perú y Colombia. Acta Cient. Venez. 27: 132-140.

Reig OA, Trainer M and Barros MA (1979). Sur l'ídentification chromosomique de Proechimys guyannensis (E. Geoffroy, 1803) et de Proechimys cuvieri Petter, 1978 (Rodentia, Echimyidae). Mammalia 43: 501-505.

Robbins LW and Baker RJ (1981). An assessment of the nature of chromosomal rearrangements in 18 species of Peromyscus (Rodentia: Cricetidae). Cytogenet. Cell Genet. 31: 194-202.

Rodrigues FHG, Silveira L, Jácomo ATA, Carmignotto AP, et al. (2002). Composição e caracterização da fauna de mamíferos do Parque Nacional das Emas, Goiás, Brasil. Rev. Bras. Zool. 19: 589-600.

Seabright M (1971). A rapid banding technique for human chromosomes. Lancet 2: 971-972.

Sumner AT (1972). A simple technique for demonstrating centromeric heterochromatin. Exp. Cell Res. 75: 304-306.

Weksler M, Bonvicino CR, Otazu IB and Júnior JSS (2001). Status of Proechimys roberti and P. oris (Rodentia: Echimyidae) from Eastern Amazonia and Central Brasil. J. Mammal. 82: 109-122.

Wilson DE and Reeder DM (2005). Mammal Species of the World: A Taxonomic and Geographic Reference. Smithsonian Institute Press, Washington.

Yonenaga-Yassuda Y, Souza MJ, Kasahara S, L'abbate M, et al. (1985). Supernumerary system in Proechimys iheringi iheringi (Rodentia, Echimydae) from the state of São Paulo, Brazil. Caryologia 38: 179-194. 